JOURNAL OF SECURITY AND SUSTAINABILITY ISSUES

ISSN 2029-7017 print/ISSN 2029-7025 online

2021 Volume 11

https://doi.org/10.47459/jssi.2021.11.30

\title{
PENITENTIARY POLICY AND RELIGION. SELECTED ISSUES ON THE BASIC OF POLISH SOLUTIONS
}

\author{
Jan Dezyderiusz Pol \\ Academy of Justice, 50 Wiśniowa Street, 02-520 Warsaw, Poland \\ E-mail: jan.pol@swws.edu.pl
}

Received 18 October 2020; accepted 28 March 2021; published 30 June 2021

\begin{abstract}
The author of this article, using the heritage of history, analyzes some themes that shape Polish penitentiary policy. The issuses are connected with the religious context in the area of remedial influence on people isolated in prison. Religion, which is now present in social area, was not always accepted by people who play important roles in the state and in the prison system due to their views. Therefore, the author asks the question of a potential factor that would affect the people in order to be able to function according to social expectations. It can be considered that remedial actions on the basis of religious or secular methods may be a starting point for developing an expected repair model. It is also noticed that faith and religiosity can cause the transformation of imprisoned people, initiate it.
\end{abstract}

Keywords: prison; penitentiary policy; security; religion; rehabilitation

Reference to this paper should be made as follows: Dezyderiusz Pol, J. 2021. The principles of complementary education for sustainable development. Journal of Security and Sustainability Issues, 11, 347-353. https://doi.org/10.47459/jssi.2021.11.30

JEL Classifications: D63

\section{Introduction}

When undertaking an analysis of historical sources and an attempt to sort out issues related to Polish penitentiary policy, we encounter a multitude of literature in the field of prison, prison studies, criminal and criminal executive law, and penitentiary issues related to psychology and sociology. At the beginning of what, in time, became a penitentiary system and penitentiary policy, was (in accordance with the standards of the time) the ordinary detention of people committing criminal acts in dungeons and towers. This initial "prison technique" has evolved from mutational punishment and torment - to keep a man in relative health, with the possibility of corrective action. (Śliwowski, 1982, 83) Gradually introduced changes were correlated with the birth of scientific interests, which resulted in specific solutions used worldwide, in Europe and in Poland. The prison system and education about it were the basis for initiating a penitentiary policy developed systematically in the 1920s and 1930s.were the basis for initiating a penitentiary policy developed systematically in the 1920s and 1930s. Developing various scientific fields such as medicine, criminology, psychology, both in Europe and in the USA, there has been an evolution in views regarding ways of influencing people deprived of their liberty. "... at the turn of the nineteenth and twentieth centuries, the change of an offender imprisoned into a law-abiding person meant his moral improvement, and the catalog of measures enabling this improvement included work, discipline, and moral and religious teachings." (Stańdo-Kawecka 2020. 19) In socialist countries, which after the war were mastered by socialism, all initiatives and penitentiary practice were subordinated and dependent on the communist ideology and served exclusively restrictive policy objectives, regardless of scientific achievements. (See 20-21) As a result, there was a certain delay in the Polish penitentiary system. There were attempts to gradually catch up after the change of political system. 


\section{Historical determinants of Polish penitentiary policy}

Poland's political situation is fraught with historical consequences and this is the result of further solutions also undertaken in the penitentiary system reforms. "The lands of the reviving Polish state were in every respect a legal mosaic, which also concerned substantive criminal law: in the lands before the First World War under Russian rule, the Russian Penal Code from 1903 was in force, in the German territories, the penal code of the former Second Reich from 1871, in pro-Austrian territories - the code from 1852, and the uncodified Hungarian penal law in the Spišs, Orava and Chadecki district." (Lityński 2012, 209) Referring to historical threads related to the partitions of Poland, i.e. dependent on various legal systems, and applying particular legal solutions, ended with the activity of the state, which initiated regaining independence in 1918. From this event, we can see important reforms for the country in various areas of social, economic and political life. Legal regulations concerning minors and adults who felt foul with the law became particularly important issues to be solved.

Penitentiary policy is a theory and practice located in the area of punishment (criminal law) and detention and its execution. This is possible thanks to the possibility of using an appropriate penitentiary system. Theory these are the premises for the types and forms of punishment formulated on the basis of various scientific disciplines, e.g. legal and social sciences - then there is talk of a criminal policy that determines what penalties, punitive measures will be applied by the judiciary. Practice - this is execution, i.e. the implementation of the prescribed penalties in an appropriate way. In the case of detention, it shall be carried out by prison units, such as a remand centre and a penitentiary. (Stańdo-Kawecka, 2000,34) "The policy of executing a penalty of detention of liberty is referred as penitentiary policy, and the policy of influencing the use of punishments and punitive measures by courts - as a criminal policy.( See 34) After World War II, the issues of penitentiary policy were repeatedly addressed in Poland for various reasons. With the development of the doctrine of the socialist state and scientific analyses - theoretical and practical - an attempt was made to define and apply subsequent solutions in penitentiary services. Therefore, it is worthwhile to present the views of selected scientists - theoreticians and practitioners, defining the scope, purpose and solutions used in Polish penitentiary policy. The adopted chronology is a peculiar calendar and a kaleidoscope of assumptions relevant to the history and modernity of the achievements of the Polish prison, which was experiencing an evolution based on political changes in our country. M. Porowski claimed that "“'Penitentiary policy is reforming, the essence of prison - no. /.../ the only reaction can be changes in the way the penalty of deprivation of liberty is executed. (Porowski 1998, 349) The title of the article, which encourages discourse, indicates the area and substantive scope of the issue. The combination of such distant spheres influencing man - religion and socialisation - might seem doomed to failure, but as praxis shows, this combination is not meaningless. These considerations also have their theoretical and practical justification.

Is there a need to give "to the Emperor - that which is imperial and to God - that which is divine", carrying out corrective actions? Or is this recommendation worth applying in other circumstances? According to the author of this article, it is worthwhile to refer to the words of John Paul II's encyclical Fides et ratio: "Faith and reason are like two wings on which the human spirit rises to the contemplation of truth. /.../ Faith without thinking and thinking without faith are dangerous. (John Paul II) Considering this issue from a philosophical point of view, one can quote Hegel's position from his "Lectures on the philosophy of religion": "... A nation that has the wrong concept of God also has a bad state, a bad government, bad laws." (Hegel 2006, 245) An emphatic statement is also the speech of Pope Benedict in the Bundestag, on 22nd September 2011, entitled "The listening heart": "Unlike other great religions, Christianity has never proposed a revealed law to the State and to society, that is to say a juridical order derived from revelation. Instead, it has pointed to nature and reason as the true sources of law - and to the harmony of objective and subjective reason, which naturally presupposes that both spheres are rooted in the creative reason of God." (Benedict XVI 2011) Such an approach to the issue may raise suspicion of an attempt to instrumentalise religion or to build the religiousness of modern man based on the fear of what is invisible to based on the fear of what is invisible to the senses and incomprehensible by reason. St. Paul the Apostle points out: "Indeed, when Gentiles, who do not have the law, do by nature things required by the law, they are a law for themselves, even though they do not have the law. They show that the requirements of the law are written on their hearts, their consciences also bearing witness, and their thoughts 
sometimes accusing them and at other times even defending them." (Ap. Paul) The terms "social rehabilitation" and "religion" have rich literature on the subject and there is no need to mention them in this article. It is important that these concepts constitute two points that will determine the way we move, associations (often intuitive) and determine the directions of reflection.

\section{Religion in the social-anthropological context}

According to the second thread indicated in the title, i.e. religion, we are aware, on the one hand, that we are moving in a well known cultural area, and on the other hand, talking about religion today is quite difficult. For some, it is extremely important, because the relationship with God, religiousness, religious observances - constitute an important part of life determinants, and for others - religion is a sphere completely unnecessary and do not deal with it at all. Today, a change in the approach to religion is noticeable - secularisation views are present, laicisation is progressing, as well as opinions on the pluralisation or subjectification of religion (Martínez-Ariño \& Zwilling, 2020). There is also a search for spiritual experiences outside the area of traditional religions, although the effects of such wanders are difficult to predict. "Religious observances and religion teaching have accompanied the institution of prison since the beginning of the modern prison system. This is not surprising, since crimes were considered to be sinful behaviour and religious upbringing was a fundamental factor in the moral behaviour of man. Nowadays, not all people share this view, some of them leave religion altogether, believing that it is unnecessary in human life. However, modern and law-abiding penitentiary systems of the convict's religious freedom (Tenenbaum \& Ricks, 2020) and the right to participate in religious practices do not question. Contemporary penitentiary science also recognises the educational and rehabilitation aspects of the impact of religion on man (Martínez-Ariño \& Zwilling, 2020), if the principles and commandments of religion are genuinely taken as their own worldview. In the interwar period, subsequent legal acts regarding the organization of the prison granted prisoners the right to meet with priest and to receive religious consolation. Moral and religious influence was then treated as an important means of achieving positive changes in the prisoner's personality. This is evidenced by the provisions of the prison regulations from 1931, which among the means of education and correction, mentioned pastoral care in the first place. In the post-war period there were major changes in this respect. The first post-war decade was a period during which religious practices were essentially eliminated from prison life, while since 1955, the laws granted prisoners only limited powers in this scope. The issue of prisoners' religious life was regulated in the basic acts of ordinances and instructions (Sitnik \& Mrozek 2011).

According to Victor Frankl, a human person is a unity of three dimensions: biological, psychological and spiritual. Thanks to its innate possibilities, such as freedom, intentionality, responsibility, it enters into a relationship with itself and establishes it with the other person and with God. In this way, as Frankl says, he becomes "himself fully" (Głaz 2007)

In the anthropological, socio-psychological and religious context, many questions arise related to the role and importance of religion, religiousness and religious observances for the REMEDIAL/RECOVERY process carried out in penitentiary units. The role of the state in shaping penitentiary policy as well as the role of the Prison Service in executing, in accordance with the law, penalty of deprivation of liberty. Sharp assessment of the axiology of the just punishment system may raise various reflections, but may also lead to specific actions and reforms. "Today's attitude to the new philosophy of punishment is rather façade, populist. This is closely related to the fact that the punishment predominantly bear by the government and the dominant political current. The prison system is not responsible for the way the penalty is executed. /.../ many politicians, by referring to outdated and ineffective criminal theories, negatively generate public awareness and promote a populist view of criminal matters." (Bałandynowicz 2003, 34) Will we, therefore, build subsequent stages of the society and institutions responsible for education WITH or WITHOUT point of reference, which is faith in God and the moral obligations arising from it? Will we be apt to recognition the role and importance of religious values positively shaping a man? (Mazurkiewicz 2017; Kanarek-Lizik 2021)

"Will the naked public space sterilised by the state, better fulfill its control, integrating, opinion-forming, charitable and educational function? /.../ Will schools without religion classes better bring up children; hospitals 
without chaplains more effectively help the seriously ill, and prisons without priests will be better rehabilitate?" (Sowiński 2018) What will the process of laicisation, abandonment of religious observances, or abandonment of certain values, also important in the secular or non-religious world, bring?

Let's consider whether the prison space can be a common space for religion and rehabilitation? Do we strive to develop a consensus that allows us to "make a profit" and not to waste our energy on disputes proving what is private and what is secular? The "for" and "against" positions permeate public debate, and are present in the considerations of practitioners and theorists of penitentiary rehabilitation, but do they bring constructive conclusions that serve solutions accepted by followers of religion and institutions handle with penalty of deprivation of liberty? "Religion, by providing a frame of reference that surpasses empirically available "here and now", remains a support for individuals in situations of uncertainty of fate, failures and disappointments, integrates them into groups, integrating them with recognized values and norms, which is contributor to increasing social control and limiting deviance; promotes self-determination (identification), leading individuals through various phases of life. However, the social importance of religion is not limited to the stabilisation of the existing social order, paradoxically, its prophetic function exposes the tension between idea and structure and calls for the implementation of high normative standards in all historical conditions.deviation; it fosters self-determination (identification), guiding individuals through different phases of life." (Sroczyńska 2018, 167-168) "The Church has no ready-made project, no university school, no society [let's add culture], but she does have a project of a man, a new man, reborn by grace.” (John Paul 1979)

If we assume that religion has not lost its meaning for contemporary man, where should we look for its influence in the penitentiary context discussed here? If it were possible to orient religious systems and their impacts on the ethical dimension, would it affect the right decisions and correction processes, despite many ideological differences of worldviews? "In the analyses conducted, the reference to the institutional model of Catholicism still dominates (Nowak, 2020; Getek \& Walker Grimes, 2021). It assumes the use of quantitative verbal and observational indicators, concerning: global confession of faith, religious knowledge, beliefs, religious experience, participation in obligatory and superimposed practices, bonds with the religious community, morality. However, the processes taking place in modernised societies, connected with the process of individualisation and pluralisation of the religious scene, lead to the increasing use of qualitative research methods, based on biographical analysis, in-depth interviews or participatory observation, and empirical studies increasingly refer to triangulation strategies" (Sroczyńska 2018, 171) Both, religion and social rehabilitation, demand that people participating in specific practices effectively use the opportunities arising from the place and circumstances of the penalty of deprivation of liberty. Religion, religious observances and the correction process during isolation naturally focus on the effectiveness and durability of human-changing interactions. We put together two separate ideas here, but we should remember that achieving positive results would cause true social optimism. (Pol 2019) ${ }^{1}$ Perhaps it is in the juxtaposition to these different methods of influencing a person deprived of freedom that there is a new potential?

"Theoria", "praxis" and "poiesis" is an ordered triad referring to the contemplation of truth, doing good, and the formation of externally beautiful things that inspire admiration and their pleasure." (Mróz 2014, 249)

\section{Religion in the penitentiary space}

We can assume that both, religion and secular penitentiary views, focused on human remedial actions - have the potential that is the basis for initiating and implementing the principles of functioning of people after leaving prison in order to meet social expectations. Both, secular and religious life based on honesty, truth and other values is expected by various persons and institutions - religious and secular.

\footnotetext{
1 I invite you to read publications that specified the concepts of religion and resocialization, as well as the area of interaction. See http://jandezyderiuszpol.pl/publication/religijne-inspiracje-w-resocjalizacji-penitencjarnej/, and http://jandezyderiuszpol.pl/publication/view/czy-religia-jest-w-wiezieniu-potrzebna/ (access on 18.12.2020).
} 
"In sociological analysis, a pluralistic society - due to its liberal nature - is sometimes referred to as the society of choice." (Adamski 2019)

Maybe there is a need a sterile desert in which will we only gradually arrange model solutions? But what then with the current access to data and already developed legal, pedagogical, rehabilitation solutions, supported by obligatory religious principles? "The subject thus decides, on the basis of his or her experience, what he or she considers to be sustainable in religious matters and the subjective "conscience" becomes the only judge of what is ethical. In this way, ethics and religion lose the power to create a community and become a completely personal matter. This is a dangerous state of humanity, as we see from the disturbing pathologies of religion and reason, which necessarily explode when reason is so reduced that questions of religion and ethics no longer concern him. Attempts to construct ethics from the rules of evolution or from psychology and sociology prove to be simply inadequate." (Benedict XVI 2006) The "queen of punishments" - isolation - can therefore be a space exploited by both religion and broadly understood rehabilitation. The most important issue remains, i.e. the competences and methods used to implement the principles propagated and used by religion or rehabilitation. Does the "ora et labora" - meaning religious "pray" and secular / non-religious "labora" - properly express the focus on those influences that should be used for successive work on a man deprived of his freedom? "There is no "religious rehabilitation", as well as there is no "rehabilitation religion". Both fields - rehabilitation and religion, come from different sources and traditions, use different ways of influencing, but they can and should meet on the basis of effective methods impact on people who have come into conflict with the law.

"Both "fascination" and "disenchantment" accompany the presence of religion in the complex socio-cultural contexts of today's world and the Church, and the associated religiosity in strongly modernised societies, although they do not avoid the influences and consequences of secularisation processes, they continue to play, in the conditions of pragmatism values, the role of a consistent source of public values (especially trust and credibility) and a common space of moral discourse, necessary in socialisation processes." (Sroczyńska 2018, 172)

An unambiguous description of the relationship: religion - religiousness - rehabilitation is, however, difficult and rarely used in scientific studies, nevertheless, these two different, seemingly, orders can meet and permeate each other wherever possible in relation to the correction process and social readaptation of people isolated in penitentiary units (Pol 2014; Grzesiak 2021).

Returning to the questions posed earlier, it is necessary to consider whether prisons deprived of priests will be better rehabilitated? Will the rehabilitation supported by pastoral activities of clergy of different confessions meet the expectations of non-religious luminaries of rehabilitation?

The words "I have no faith, please don't bother", spoken in prison by J. Fesch to the chaplain and what happened in his life later, are an example of a very interesting transformation. (Gość.pl 2021) Even when the religious themes in one's life are abandoned or dismissed, one remains open to a sphere that transcends one's feelings and the decision to deny faith. „Interesting are the statements diagnosing the religious situation in the Czech Republic. "There was no revival of religious life in the Czech Republic in the nineteenth and twentieth centuries, but we can speak of the phenomenon of secularization of religion. The outstanding Czech philosopher Jan Patočka in the famous essay entitled "Who are the Czechs" mentions "secular Christianity" (Zenderowski 2018, 208) Leszek Kołakowski's statement Religion does not die because there is nowhere to die (Kołakowski 2005, 303) - and Jesus' words - you will recognise them by their fruits (Mt 7,16) they will be used for us as a proper rule in penitentiary work, although, ... good structures help, but they are not enough. (Benedict XVI, n 25) "Pastoral efforts are of great importance in the spiritual renewal of prisoners, which is also confirmed by the results of empirical analyses. The first rule is that the high frequency of religious observances is associated with an increase in prosocial behavior. Highly religious prisoners are more disciplined, less likely to commit crimes while serving their sentence, and have fewer interpersonal conflicts - with both inmates and staff. Secondly, convicts with high religious sensitivity towards those who have external religious motivation and in relation to non-believing prisoners are characterised by a greater sense of guilt for the crime committed and a more positive attitude to moral norms. People participating in religious programs experience less often negative emotions 
in the form of anger, bitterness and emotional coldness. In addition, studies of the relationship between religiousness and cognitive functioning have shown that high spiritual formation coexists with a high level of selfefficacy and goals focused on realising the values derived from the decalogue (Niewiadomska 2016, 115-116)".

\section{Conclusions}

Priests of the Catholic Church undertake many different activities in pastoral practice. Similarly, chaplains of other faiths or religious associations do their ministry. From the information obtained from individual chaplains, it is known that they take action primarily for the benefit of prisoners, but it also happens that they also serve the employees and officers, which since June 21, 2018, i.e. when Saint. Paul Apostle was established as a patron of the Polish Prison Service - should be a natural element of the ministry of a prison chaplain. It should be emphasised that prison ministry cannot and should not replace rehabilitation, although it should be recognised as an important element of the correction process. Modern rehabilitation of convicted persons is becoming an activity that cannot be based solely on classical methods and remedial measures - which resounds repeatedly in the scientific literature dealing with these issues. Practice shows that the search for other solutions is a chance to implement correction process that will result in a better moral condition and sense of the world of values. (Pol 2014).

\section{References}

Adamski, F. (2021). Pluralizm wartości a wychowanie [Pluralism of values and education]. Fides et ratio, 80-85.

Bałandynowicz, A. (2003). Filozofia probacji. Podstawy aksjologiczne systemu sprawiedliwego [The philosophy of probation. Axiological foundations of the just system]. Prokuratura i Prawo, 2, 7-28.

Benedict XVI. (2007). Encyclical Spe salvi. Vox Patrum. Civitas Vaticana.

Benedict XVI. (2011). Pope speech in Bundestag. https://ekai.pl/dokumenty/przemowienie-benedykta-Xvi-w-bundestagu-z-22-wrzesnia-2011-r/

Benedict, XVI. (2006). Pope speech in Regensburg. https://opoka.org.pl/biblioteka/W/WP/benedykt_xvi/podroze/ben16ratyzbona_12092006.html

Getek, S.K., Walker Grimes, K. (2021). Order, Reform, and Abolition: Changes in Catholic Theological Imagination on Prisons and Punishment. Theological Studies, 82(1), 95-115.

Głaz, S. (2007). Antropologiczny wymiar przeżycia obecności i nieobecności Boga [The anthropological dimension of experiencing the presence and absence of God]. Studia Psychologica, 7, 375-384.

Grzesiak, S. (2021). Effective management of the resources of the social readaptation system. From "silo" solutions to the integration approach - the case of Poland. Entrepreneurship and Sustainability Issues, 11(1), 91-101.

Hegel, G.W.F. (2006). Wykłady z filozofii religii [Lectures on the philosophy of religion]. Part I. Wydawnictwo PWN.

John Paul II. (1998). Encyclic Fides et ratio. Civitas Vaticana.

John Paul II. (1979, April 3). Homily to students. Papal Teaching. Pallottinum.

Kanarek-Lizik, D. (2021). The education of prison service officers: tendencies and changes in the framework of security. Journal of Security and Sustainability Issues, 11, 83-90.

Kołakowski, L. (2005). Mini wykłady o maxi sprawach, Trzy serie [Mini lectures on maxi matters, Three series]. Znak.

Lityński, A. (2012). Dwa Kodeksy karne 1932. W osiemdziesiątą rocznicę [Two Penal Codes 1932. On the 80th anniversary]. Teoria i praktyka, 12, 207-218.

Martínez-Ariño, J., Zwilling, A.L. (Eds.). (2020). Religion and Prison: An Overview of Contemporary Europe. Springer.

Mazurkiewicz, P. (2018, March 12). Opening lecture during conference Polonia Restituta. https://politologiareligii.pl/multimedia/83/ ks-prof-piotr-mazurkiewicz-konferencja-polonia-restituta 
Mróz, M. (2014). Cnoty rozumu w obronie kultury i wiary: wokół myśli św. Tomasza z Akwinu [The virtues of reason in defense of culture and faith: around the thought of St. Thomas Aquinas]. Studia Pelplińskie, 47, 243-260.

Niewiadomska, I. (2016). Polski model resocjalizacji penitencjarnej [Polish model of penitentiary social rehabilitation]. Teka Komisji Prawniczej PAN Oddział w Lublinie, 9, 100-122

Nowak, B.M. (2020). [Nie]skazani na wykluczenie. Od patologii do normy zachowań społecznych [Non-imprisonment to exclusion. From pathology to the norm of social behavior]. Wyższa Szkoła Kryminologii i Penitencjarystyki w Warszawie.

Pol, J.D. (2014). Religijne inspiracje w resocjalizacji penitencjarnej [Religious inspirations in penitentiary social rehabilitation]. In: K. Marzec Holka, K. Mirosław-Nawrocka, J. Molenda (Ed.), Współczesne uwarunkowania i wzory procesów resocjalizacji, reintegracji, inkluzji [Contemporary conditions and patterns of social rehabilitation, reintegration and inclusion processes]. Wydawnictwo Akademii Pedagogiki Specjalnej.

Pol, J.D. (2013, March 13). Czy religia jest w więzieniu koniecznie potrzebna? [Is religion absolutely necessary in prison?]. http:// jandezyderiuszpol.pl /publication/view/czy-religia-jest-w-wiezieniu-potrzebna/

Porowski, M. (1998). O kulturowej tożsamości więzień [On the cultural identity of prisons]. In: M. Porowski (Ed.), IPSiR dzisiaj. Księga Jubileuszowa. Uniwersytet Warszawski.

Sitnik, K., Mrozek, K. (2011). Prawo skazanych do korzystania z wolności religijnej [The right of convicts to exercise religious freedom]. Przegląd Prawa Konstytucyjnego, 4(8), 205-224.

Sowiński, S. (2010). Kościelna wieża w nowoczesnym mieście [A church tower in a modern city]. Więź, 11-12.

Eljasz-Radzikowski, S., Goetl, W., Semkowicz, W., Zawiliński, R. (1919). Spisz, Orawa i okręg Czadecki [Spisz, Orawa and the Czadecki district]. Komitet Narodowy Obrony Spisza, Orawy, Czadeckiego i Podhala.

Sroczyńska, M. (2018). O potrzebie religii w ponowoczesnym świecie (refleksje socjologa) [On the need of religion in the postmodern world (reflections of a sociologist)]. Chrześcijaństwo, świat, polityka. Zeszyty myśli społecznej Kościoła, 22, 166-175.

Stańdo-Kawecka, B. (2000). Prawne podstawy resocjalizacji [Legal grounds for rehabilitation]. Zakamycze.

Śliwowski, J. (1982). Prawo i polityka penitencjarna [Penitentiary law and policy]. Państwowe Wydawnictwo Naukowe.

Tenenbaum, E., Ricks, S.E. (2020). Protecting Freedom of Religion in Prison: The Free Exercise Clause and RLUIPA. CURRENT ISSUES IN CONSTITUTIONAL LITIGATION: A CONTEXT AND PRACTICE CASEBOOK. 3rd ed. Carolina Academic Press.

Zenderowski, R. (2018). Nowoczesna tożsamość narodowa budowana na zeświecczonej tradycji religijnej (przypadek czeski) [A modern national identity built on a secularized religious tradition (Czech case)]. Chrześcijaństwo, świat, polityka. Zeszyty myśli społecznej Kościoła, 22, 199-210.

Jan DEZYDERIUSZ POL since 1998 - academic lecturer, currently assistant professor at the Academy of Criminology and Penitentiary Studies in Warsaw. Since 2017, the coordinator of the prison chaplaincy of the Catholic Church in the Office of the Chief Prison Chaplain in the Prison Service., author of many publications in the field of sociology, penitentiary studies, prison chaplaincy, social work, pedagogy. Research interests: penitentiary policy, religion, volunteering, prison rehabilitation.

ORCID ID: 0000-00020362506361

This work is licensed under the Creative Commons Attribution International License (CC BY). http://creativecommons.org/licenses/by/4.0/ 